\title{
The Thrombin Receptor Extracellular Domaiñ Contains Sites Crucial for Peptide Ligand-induced Activation
}

\author{
Wadie F. Bahou, ${ }^{\star}$ Barry S. Coller, ${ }^{\star \ddagger}$ Cheri L. Potter, ${ }^{\star}$ Karin J. Norton, ${ }^{\star}$ Jeffery L. Kutok, ${ }^{\star}$ and Michael S. Goligorsky ${ }^{\star \S}$ \\ Departments of ${ }^{*}$ Medicine, ${ }^{\ddagger}$ Pathology, and ${ }^{\S}$ Physiology and Biophysics, State University of New York, Stony Brook, New York 11794
}

\begin{abstract}
A thrombin receptor (TR) demonstrating a unique activation mechanism has recently been isolated from a megakaryocytic (Dami) cell line. To further study determinants of peptide ligand-mediated activation phenomenon, we have isolated, cloned, and stably expressed the identical receptor from a human umbilical vein endothelial cell (HUVEC) library. Chinese hamster ovary (CHO) cells expressing a functional TR (CHOTR), platelets, and HUVECs were then used to specifically characterize $\alpha$-thrombin- and peptide ligand-induced activation responses using two different antibodies: anti-TR ${ }^{34-52}$ directed against a 20 -amino acid peptide spanning the thrombin cleavage site, and anti-TR ${ }^{1-160}$ generated against the $\mathrm{NH}_{2}$-terminal 160 amino acids of the TR expressed as a chimeric protein in Escherichia coli. Activation-dependent responses to both $\alpha$ thrombin (10 $\mathrm{nM})$ and peptide ligand $(20 \mu \mathrm{M})$ were studied using fura 2-loaded cells and microspectrofluorimetry. Whereas preincubation of CHO-TR with anti-TR ${ }^{34-52}$ abolished only $\alpha$-thrombin-induced $\left[\mathrm{Ca}^{2+}\right]$ transients, preincubation with anti-TR ${ }^{1-160}$ abrogated both $\alpha$-thrombin- and peptide ligand-induced responses. This latter inhibitory effect was dose dependent and similar for both agonists, with an $\mathrm{EC}_{50}$ of $\sim 90 \mu \mathrm{g} / \mathrm{ml}$. Anti-TR ${ }^{1-160}$ similarly abolished peptide ligandinduced $\left[\mathrm{Ca}^{2+}\right]_{i}$ transients in platelets and HUVECs, whereas qualitatively different responses characterized by delayed but sustained elevations in $\left[\mathrm{Ca}^{2+}\right]_{i}$ transients were evident using $\alpha$ thrombin. Platelet aggregation to low concentrations of both ligands was nearly abolished by anti-TR ${ }^{1-160}$, although some shape change remained; anti-TR ${ }^{34-52}$ only inhibited $\alpha$-thrombin-induced aggregation. These data establish that a critical recognition sequence for peptide ligand-mediated receptor activation is contained on the $\mathrm{NH}_{2}$-terminal portion of the receptor, upstream from the first transmembrane domain. Furthermore, $\alpha$-thrombin-induced activation of HUVECs and platelets may be partially mediated by an alternative mechanism(s) or receptor(s). (J. Clin. Invest. 1993. 91:1405-1413.) Key words: thrombin • endothelial cells • platelets • receptor activation • calcium
\end{abstract}

\section{Introduction}

$\alpha$-Thrombin initiates a molecular dialogue between platelets, the endothelium, and other coagulation proteins that is funda-

Address correspondence to Wadie F. Bahou, Division of Hematology, HSC T-15/040, State University of New York, Stony Brook, NY 11794-8151.

Received for publication 29 May 1992 and in revised form 29 September 1992.

J. Clin. Invest.

(C) The American Society for Clinical Investigation, Inc.

0021-9738/93/04/1405/09 \$2.00

Volume 91, April 1993, 1405-1413 mental to the ultimate control of the hemostatic response. In addition to its well-defined role in coagulation (1), $\alpha$-thrombin is among the most potent of physiological stimuli for platelet activation (2). Interaction of $\alpha$-thrombin with the endothelium results in the release of von Willebrand factor, modulation of fibrinolytic activity, and endothelial cell retraction, resulting in selective permeability of the vascular wall (3). A receptor for $\alpha$-thrombin has recently been isolated by expression cloning in Xenopus oocytes using mRNA from the Dami megakaryocytic cell line (4). This receptor is structurally similar to other members of the seven-transmembrane receptor family (5), elicits elevation of cytosolic calcium in response to physiological doses of $\alpha$-thrombin, and fails to respond to D-phenylalanyl-prolyl-arginine chloromethyl ketone (PPACK)- and hirudin-treated thrombin. A putative thrombin cleavage site has been identified, and a 14-amino acid peptide mimicking the new $\mathrm{NH}_{2}$ terminus has been shown to act as a potent agonist for activation of platelets $(4,6)$, endothelial cells (7), and other cells $(8,9)$ expressing similar thrombin receptors (TRs). ${ }^{1}$ In platelets, both the peptide and proteolytically active thrombin similarly lead to phospholipase $\mathrm{C}$ and 3-phosphorylated phosphoinositide (3,4-bisphosphate and 3,4,5-trisphosphate) accumulation (10) and both inhibit adenylate cyclase activity (11). Smaller peptides derived from the new $\mathrm{NH}_{2}$ terminus may equally or more potently activate the receptor (12).

We have initiated studies designed to address structural features of peptide ligand-mediated thrombin receptor cell activation. We have isolated, cloned, and stably expressed a TR from a human umbilical vein endothelial cell (HUVEC) library and demonstrated that it is structurally identical to its platelet-derived counterpart. Comparative activation-dependent responses to both $\alpha$-thrombin and peptide ligand were subsequently evaluated in stably transfected Chinese hamster ovary (CHO) cells (CHO-TR), cultured endothelial cells, and platelets, using two antibodies directed against different regions of the receptor. One antibody (anti-TR ${ }^{1-160}$ ), directed against a bacterially expressed segment of this receptor, completely abrogated peptide ligand-induced elevations in cytosolic calcium concentration $\left(\left[\mathrm{Ca}^{2+}\right]_{i}\right)$ in transfected $\mathrm{CHO}$ cells, endothelial cells, and platelets when evaluated by microspectrofluorimetry of fura 2-loaded cells. Although anti-TR ${ }^{1-160}$ similarly abolished $\alpha$-thrombin-mediated $\left[\mathrm{Ca}^{2+}\right]_{\mathrm{i}}$ in transfected $\mathrm{CHO}$ cells, qualitatively different responses characterized by delayed but sustained elevation in $\left[\mathrm{Ca}^{2+}\right]_{i}$ were observed with both platelets and endothelial cells. An antibody directed to a peptide encompassing the thrombin cleavage site (anti-TR ${ }^{34-52}$ ) abolished thrombin-mediated activation, but not activation induced by the peptide ligand. These data suggest that a critical recognition sequence for peptide ligand-associated receptor activation is

1. Abbreviations used in this paper: $\mathrm{ACD}$, acid-citrate dextrose; $\mathrm{CHO}$, Chinese hamster ovary; GFP, gel-filtered platelets; HBMT, Hepes-buffered modified Tyrodes; HUVEC, human umbilical vein endothelial cell; MTX methotrexate; PCR, polymerase chain reaction; TR, thrombin receptor; TSE, Tris-saline-EDTA. 
restricted to a region within the $\mathrm{NH}_{2}$-terminal portion of the receptor, situated upstream from the first transmembrane domain. Furthermore, thrombin-induced activation of HUVECs and platelets may be partially mediated by an alternative mechanism(s).

\section{Methods}

Reagents and peptides. Purified human $\alpha$-thrombin $(\sim 3,500 \mathrm{U} / \mathrm{mg}, 1$ $\mathrm{nM} \sim 0.1 \mathrm{U} / \mathrm{ml}$ ) was kindly supplied by Dr. J. Jesty (State University of New York at Stony Brook). Two peptide ligands representing the new $\mathrm{NH}_{2}$ terminus of the TR after thrombin cleavage were synthesized, one of 11 amino acids (TR ${ }^{42-52}$, SFLLRNPNDKY) and the other of 14 amino acids (TR ${ }^{42-55}$, SFLLRNPNDKYEPF). Preliminary studies demonstrated that both peptides aggregated platelets in a similar manner, with the 11-mer $\mathrm{TR}^{34-52}$ displaying slightly more activity (13). A functionally inactive 14-amino acid peptide spanning residues 42-55 (T1C2, FSLLRNPNDKYEPF) in which the first two residues were reversed in position was synthesized as a control. A 20-amino acid peptide encompassing the thrombin cleavage site with an added $\mathrm{NH}_{2}$-terminal cysteine (TR ${ }^{34-52}$, Ac-CTNATLDPRSFLLRNPNDKY$\mathrm{NH}_{2}$ ) was synthesized for use as an immunogen (see below). All peptides were synthesized using t-boc chemistry on an automated synthesizer (Model 430A; Applied Biosystems, Inc., Foster City, CA) as $\mathrm{COOH}$-terminal amides and with acetylated $\mathrm{NH}_{2}$ termini. The $\mathrm{TR}^{34-52}$ peptide was treated with base to reverse any $\mathrm{N} \rightarrow \mathrm{O}$ shift of the serine and threonine residues and purified by reverse-phase HPLC. Restriction enzymes were purchased from Stratagene, Inc. (La Jolla, CA), Fura 2/AM from Molecular Probes, Inc. (Eugene, OR), and PGE, from Sigma Chemical Co. (St. Louis, MO).

Isolation and $c D N A$ cloning of endothelial cell-derived TR. The construction of both random-primed and oligo(dT)-primed HUVEC cDNA libraries cloned into the expression vector $\lambda$ gt- 11 has been previously described (14). cDNA inserts were directly labeled in $1 \%$ low melting agarose by random hexamer priming (15) and used for further screening by standard techniques (16). Sequence analysis was completed in M13mp18 using dideoxy chain termination (17) and T7 DNA polymerase (Sequenase; U.S. Biochemical Corp., Cleveland, $\mathrm{OH})$. Oligonucleotides were synthesized on an single channel synthesizer (Applied Biosystems, Inc.). The polymerase chain reaction (PCR) was completed using 35 rounds on a thermocycler (Coy Laboratory Products Inc., Ann Arbor, MI) as previously described (18), and products were analyzed by electrophoresis in a $1 \%$ ethidium-stained agarose gel. The amplifications performed directly from the HUVEC library were completed after boiling the phage template DNA for $3 \mathrm{~min}$. Reverse transcription was completed by incubating $3 \mu \mathrm{g}$ of endothelial cell RNA (19) with $1 \mu \mathrm{g}$ of a 14 -mer oligo(dT) primer at $41^{\circ} \mathrm{C}$ for $1 \mathrm{~h}$ using avian myeloblastosis virus reverse transcriptase (Seikagaku America Inc., Rockville, MD). $10 \mu \mathrm{l}$ of a $50-\mu \mathrm{l}$ sample was then used in the PCR as previously described (20).

Production of recombinant protein and antibody generation. The PCR fragment containing flanking BamHI and EcoRI restriction sites was purified by agarose gel electrophoresis, double digested, and directionally cloned in-frame into the prokaryotic expression vector pGEX2T (Pharmacia LKB Biotechnology Inc., Piscataway, NJ), thereby generating a chimeric fusion protein consisting of glutathione$S$-transferase and a portion of the TR $\left(T^{1-160}\right)$. The plasmid was transformed into Escherichia coli host strain Y1090, and fusion proteins were produced in liquid culture by induction with $10 \mathrm{mM}$ isopropyl- $\beta$ D-thiogalactopyranoside for $2 \mathrm{~h}$ at $37^{\circ} \mathrm{C}$. After lysis in a Dounce homogenizer, the insoluble fraction containing the recombinant protein was solubilized in $6 \mathrm{M}$ guanidine hydrochloride and $10 \mathrm{mM}$ DTT for $60 \mathrm{~min}$ at $25^{\circ} \mathrm{C}$, and then renatured by stepwise dialysis at $4^{\circ} \mathrm{C}$ against decreasing concentrations of guanidine and PBS (137 mM NaCl, 2.7 $\mathrm{mM} \mathrm{KCl}, 4.3 \mathrm{mM} \mathrm{Na}_{2} \mathrm{HPO}_{4}$, and $1.4 \mathrm{mM} \mathrm{KH}_{2} \mathrm{PO}_{4}$ ). The protein was then affinity purified by incubation with glutathione-Sepharose beads (Sigma Chemical Co.) and analyzed by SDS-PAGE. For the generation of a specific antibody (anti-TR ${ }^{1-160}$ ), the recombinant protein was excised as a discrete band from an $8 \%$ SDS-PAGE gel, electroeluted, and suspended in complete Freund's adjuvant for injection into a rabbit. Approximately $100 \mu \mathrm{g}$ of protein was administered on day 1 , and three subsequent boosts of the protein suspended in incomplete Freund's adjuvant were given at days 14,28 , and 42 ; the animal was bled for serum isolation on day 56 .

The 20-mer peptide encompassing the thrombin cleavage site $\mathrm{TR}^{34-52}$ was coupled to keyhole limpet hemocyanin (Calbiochem Corp., La Jolla, CA) by two different methods: crosslinking of the free sulfhydryl group on the peptide to the amino groups on the keyhole limpet hemocyanin via the heterobifunctional cross-linking reagent mal-sac-HNSA (Bachem Bioscience Inc., Philadelphia, PA) and crosslinking of the lysine amino group on the peptide to the amino group on the keyhole limpet hemocyanin by glutaraldehyde. New Zealand white rabbits were immunized with $1 \mathrm{mg}$ of a mixture of the cross-linked peptides in complete Freund's adjuvant and boosted four times with cross-linked peptide in incomplete Freund's adjuvant. Antisera (anti$T^{34-52}$ ) were initially screened by ELISA using immobilized peptide. Further details describing the production and characterization of this antibody are being separately reported (Norton, K., and B. Coller, manuscript in preparation). IgG-containing fractions for both anti$\mathrm{TR}^{34-52}$ and anti-TR ${ }^{1-160}$ were purified by protein A-Sepharose chromatography, and $\mathrm{F}\left(\mathrm{ab}^{\prime}\right)_{2}$ fragments were prepared by overnight pepsin digestion $\left(0.5-2.0 \% \mathrm{wt} / \mathrm{wt}\right.$, $\left.\mathrm{pH} 4.0,37^{\circ} \mathrm{C}\right)$.

Functional expression. A full-length construct containing the TR open reading frame and the consensus initiation sequence cloned into the BamHI site of pBluescript (Stratagene Inc., La Jolla, CA) was "shuttled" into the polylinker of the plasmid pGEM (Promega Corp., Madison, WI), thereby generating flanking external PstI and EcoRI sites. These newly created ends were then used for proper orientationspecific ligation into the eukaryotic expression vector pMT2 (21)(designated PMT2-TR), which contains an inherent dihydrofolate reductase gene, thereby allowing for selection and amplification of plasmid-bearing cells when grown in increasing concentrations of methotrexate (MTX). Dihydrotolate reductase-deficient CHO cells (22) were propagated in CHO-S-SFM medium (Gibco-BRL, Gaithersburg, MD) supplemented with $10 \%$ dialyzed fetal calf serum (Sigma Chemical Co.) and subsequently plated at a density of $5 \times 10^{5}$ cells $/ 100-\mathrm{mm}^{2}$ dish. 20 $\mu \mathrm{g}$ of pMT2-TR or pMT2-wild type (pMT2-WT) was used for transfection by the calcium phosphate precipitation method of Chen and Okayama (23). After $5 \mathrm{~d}$, selection and amplification was initiated by supplementation of the media with $0.02 \mu \mathrm{M}$ MTX and cells were cloned by limiting dilution. Resistant colonies were subsequently expanded and propagated in increasing concentrations of MTX (final concentration $0.2 \mu \mathrm{M}$ ) for functional evaluation.

Monitoring of cytosolic calcium concentration. HUVECs were isolated from pooled primary cultures of human umbilical veins as previously described (18) and used in passages 2-5. Cells were grown on gelatin-coated plates in M199 supplemented with $10 \%$ fetal calf serum, $100 \mu \mathrm{g} / \mathrm{ml}$ endothelial cell growth factor (Collaborative Research, Bedford, MA), $100 \mu \mathrm{g} / \mathrm{ml}$ porcine intestinal heparin, penicillin $(100 \mathrm{U} / \mathrm{ml})$, and streptomycin $(100 \mu \mathrm{g} / \mathrm{ml})$. Confluent cells (CHO and HUVECs) were propagated on glass coverslips and exposed to serum-free medium 18-24 $\mathrm{h}$ before functional evaluation. Cells were subsequently loaded with $2.5 \mu \mathrm{M}$ fura $2 / \mathrm{AM}$ for $60 \mathrm{~min}$ at $25^{\circ} \mathrm{C}$, rinsed with $\mathrm{PBS}$, incubated in Krebs-Henseleit-bicarbonate buffer supplemented with $5 \mathrm{mM}$ Hepes (3), and placed in a Leiden temperature-controlled chamber (Medical Systems Corp., Greenvale, NY) for analysis. The chamber was mounted on the stage of an inverted microscope (Diaphot; Nikon Inc., Garden City, NY) equipped with quartz optics. Individual cells were optically isolated and alternately illuminated at wavelengths of 345 and $380 \mathrm{~nm}$ using a dual-excitation delta scan microspectrofluorimeter (Photon Technologies International, Trenton, NJ). Measurements of fluorescence intensity were performed at a rate of 20 points/s, and the ratio $345: 380$ was used to calculate $\left[\mathrm{Ca}^{2+}\right]_{i}$, applying fura $2 / \mathrm{cal}-$ cium standards as previously described (24).

Platelet cytosolic calcium transients were studied using gel-filtered 
A.

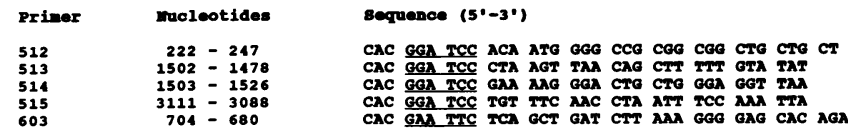

B.

1 GCACAGAGCC AGAGGGGCTI GCGAGCGGCG GCTGAGGGAC COCGGGGAGG

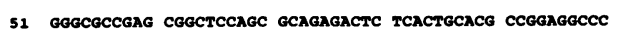

101 CTTCCTCGCT C

Figure 1. (A) Oligonucleotide primers used for isolation of endothelial cell-derived TR. Nucleotide position is according to the previously published cDNA sequence (4). Underlined sequences reflect synthetic BamHI sites, except for primer 603 , which contains a synthetic EcoRI site. The sequence highlighted in bold (primer 603 ) represents a synthetically engineered stop codon. (B) Newly identified 5 ' sequence contained in phage clone TR4-1. This nucleotide sequence has been submitted to GenBank and assigned the accession number M93111.

platelets (GFP). Platelet-rich plasma (PRP) was prepared from blood anticoagulated with acid-citrate dextrose (ACD) $(8.5 \mathrm{ml} \mathrm{blood} / 1.5 \mathrm{ml}$ ACD), supplemented with 0.1 vol of additional ACD, and centrifuged at $2,000 \mathrm{~g}$ for $8 \mathrm{~min}$ at $22^{\circ} \mathrm{C}$. The platelet pellet was resuspended in a small volume of Hepes-buffered modified-Tyrodes buffer (HMBT: 138 $\mathrm{mM} \mathrm{NaCl}, 2.7 \mathrm{mM} \mathrm{KCl}, 0.4 \mathrm{mM} \mathrm{NaH}_{2} \mathrm{PO}_{4}, 12 \mathrm{mM} \mathrm{NaHCO}_{3}, 0.2 \%$ bovine serum albumin, and $10 \mathrm{mM}$ Hepes, $\mathrm{pH}$ 7.4) supplemented with $0.1 \mu \mathrm{M} \mathrm{PGE}$, but containing no cations. Platelets were then loaded with $3 \mu \mathrm{M}$ fura $2 / \mathrm{AM}$ for $60 \mathrm{~min}$ at $37^{\circ} \mathrm{C}$, passed over a column of Sepharose 2B (Pharmacia LKB Biotechnology Inc.) and resuspended in $\mathrm{HBMT}$ supplemented with $1 \mathrm{mM} \mathrm{CaCl}$ to a final concentration of $1.5 \times 10^{8}$ platelets $/ \mathrm{ml}$. $\left[\mathrm{Ca}^{2+}\right]_{\mathrm{i}}$ transients were then evaluated in stirred platelets illuminated at $340 \mathrm{~nm}$ at $37^{\circ} \mathrm{C}$ by measuring fluorescence intensity at $500 \mathrm{~nm}$ with a spectrofluorimeter (The Perkin Elmer Corp., Norwalk, CT).

Immunocytochemistry and flow cytometric analysis. PRP prepared from healthy human donors and flow cytometric analysis were performed as previously described (25). Platelets anticoagulated with 10 mM EDTA were pelleted, resuspended in Tris-saline-EDTA (TSE) buffer (0.1 M Tris, $0.15 \mathrm{M} \mathrm{NaCl}, 10 \mathrm{mM}$ EDTA, pH 7.4), and gel filtered through Sepharose 2B equilibrated with TSE. GFP were then diluted in the same buffer to a final concentration of 3.5-4.0 $\times 10^{8}$ platelets/ml. Transfected $\mathrm{CHO}$ cells were grown in suspension culture in CHO-S-SFM serum-free media before analysis. Approximately 1-2

$\times 10^{6} \mathrm{CHO}$ cells or $400-\mu \mathrm{l}$ aliquots of GFP were incubated with specific antibodies in TSE buffer for $20 \mathrm{~min}$ at $25^{\circ} \mathrm{C}$, washed three times in TSE, and then incubated with the second affinity-purified, FITC-conjugated goat anti-rabbit $\mathrm{F}\left(\mathrm{ab}^{\prime}\right)_{2}$ antibody (Tago, Inc., Burlingame, $\mathrm{CA}$ ) at a dilution of $1: 100$ for $20 \mathrm{~min}$ at $25^{\circ} \mathrm{C}$. Cells were then washed one time in the same buffer, and one half of the sample was analyzed on a FACStar ${ }^{\otimes}$ analyzer (Becton Dickinson \& Co., Rutherford, NJ).

For immunocytochemical evaluation, endothelial cells were grown on gelatin-coated coverslips as described above. Cells were either stained live or fixed, the latter in $2 \%$ paraformaldehyde for $20 \mathrm{~min}$ at $25^{\circ} \mathrm{C}$. After fixation, cells were washed three times with PBS, incubated with $10 \%$ horse serum for $60 \mathrm{~min}$, and then with anti-TR ${ }^{1-160}(450$ $\mu \mathrm{g} / \mathrm{ml})$ or preimmune control $(450 \mu \mathrm{g} / \mathrm{ml})$ for $60 \mathrm{~min}$ at $25^{\circ} \mathrm{C}$. After three washes, cells were incubated with the FITC-conjugated goat antirabbit IgG at a dilution of 1:200 for $60 \mathrm{~min}$ before examination. Cells were studied with a fluorescence microscope using a B-dichroic mirror (Diaphot; Nikon Inc.). Images were collected with a silicon intensifier camera (Hamamatsu Photonics Microcopy, Oak Brook, IL) and processed using Universal Imaging software (Media, PA). Vital staining of live endothelial cells was performed essentially as above, omitting the fixation step and substituting Krebs-Henseleit-bicarbonate buffer for PBS. Initial images were obtained after the completion of the staining; cells were then treated with $500 \mathrm{U} / \mathrm{ml}$ trypsin (Sigma Chemical Co.) for $4 \mathrm{~min}$, followed by addition of $5,000 \mathrm{U} / \mathrm{ml}$ soybean trypsin inhibitor (Sigma Chemical Co.).

Platelet aggregation studies. For aggregation induced by $\alpha$-thrombin, GFP was prepared as described above using the HBMT buffer, except that the buffer contained $2 \mathrm{mM} \mathrm{MgCl}_{2}$. For aggregation induced by the peptide ligand, PRP was prepared from blood anticoagulated with 0.01 vol of $40 \%$ trisodium citrate. Platelets were resuspended to a final concentration of $\sim 3 \times 10^{8} / \mathrm{ml}$, and $0.45 \mathrm{ml}$ was used for aggregation studies. Preliminary experiments demonstrated maximal inhibition of platelet aggregation, induced with $1 \mathrm{nM} \alpha$-thrombin, by anti$\mathrm{TR}^{34-52}$ IgG and $\mathrm{F}\left(\mathrm{ab}^{\prime}\right)_{2}$ of 125 and $250 \mu \mathrm{g} / \mathrm{ml}$, respectively (26). Concentrations equal to or greater than these were then used in subsequent experiments. Similarly, since preincubation times of $20 \mathrm{~min}$ were sufficient to achieve maximal inhibition, subsequent studies were completed with incubation times of $\geq 20$ min.

\section{Results}

Isolation of endothelial cell-derived $T R$. The primers used for PCR are outlined in Fig. $1 \mathrm{~A}$. Primers 512/513 were used to directly amplify the TR open reading frame from both ran-
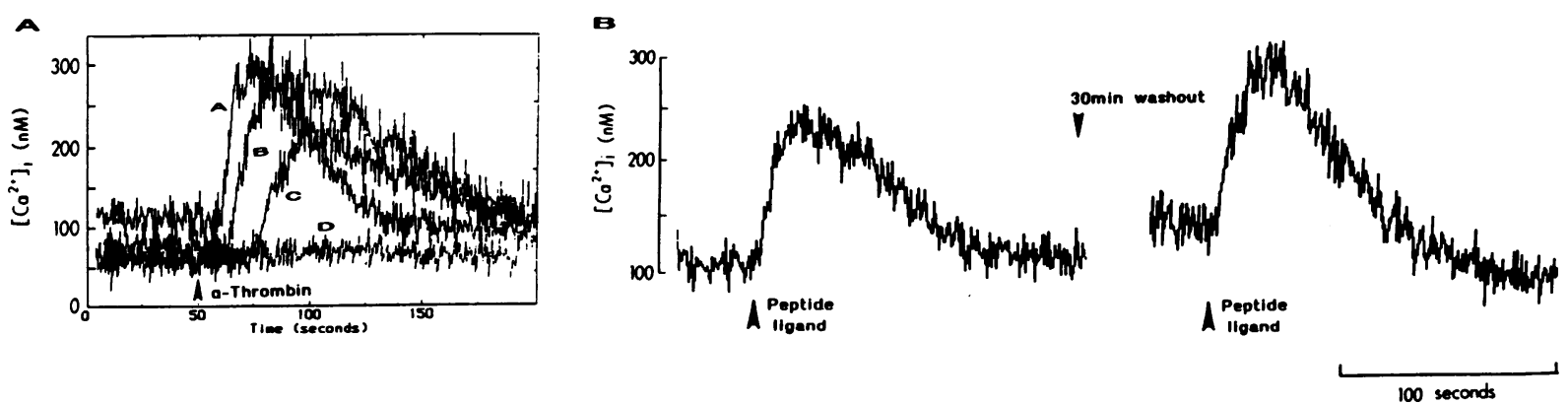

Figure 2. Activation-dependent responses of functionally expressed TR, using $\alpha$-thrombin $(A)$ or TR ${ }^{42-55}$ peptide ligand $(B)$. CHO-17 cells (see text) were grown to confluence on glass coverslips in serum-free CHO-S-SFM media, loaded with $2.5 \mu \mathrm{M}$ fura $2 / \mathrm{AM}$ for $60 \mathrm{~min}$ at $37^{\circ} \mathrm{C}$, and $\left[\mathrm{Ca}^{2+}\right]_{\mathrm{i}}$ transients were continuously monitored by microspectrofluorimetry. $(A)$ Cells were stimulated with $\alpha$-thrombin at final concentrations of $25 \mathrm{nM}$ (curve $A$ ), $10 \mathrm{nM}$ (curve $B$ ), or $2 \mathrm{nM}$ (curve $C$ ). $10 \mathrm{nM} \alpha$-thrombin is equivalent to $\sim 1 \mathrm{U} / \mathrm{ml}$. Mock-transfected CHO cells (curve $D$ ) display no evidence of $\alpha$-thrombin responsiveness (final concentration $25 \mathrm{nM}$ ). (B) Cells were activated with $20 \mu \mathrm{M}$ peptide ligand (left), rinsed with PBS, and then restimulated with the same concentration of peptide ligand 30 min later. $\left[\mathrm{Ca}^{2+}\right]_{i}$ transients after a 30 -min washout are essentially indistinguishable from those seen with the primary response. No response to mock-transfected CHO cells is evident (not shown). These results are representative of three similar experiments. 
dom- and oligo(dT)-primed HUVEC cDNA libraries. This construct includes three nucleotides upstream from the initiator methionine for maximization of ribosome initiation (27) and terminates at the end of the coding sequence. As judged by agarose gel electrophoresis, a single fragment of the appropriate size was best identified from the oligo(dT)-primed library, which was subsequently purified and cloned into M13mp18 for sequence analysis. Because primer pairs 514/515 were unsuccessful using this approach, reverse PCR was completed using endothelial cell RNA and a 14-mer oligo(dT) primer. A distinct 1,600-bp band was visualized on agarose gel electrophoresis, which was subsequently ligated into pBluescript, and its identity was confirmed by extensive restriction mapping. The coding sequence was bidirectionally sequenced and was identical to the previously published platelet-derived cDNA sequence (4), except for the following nucleotide differences: base pair $282 \mathrm{~T} \rightarrow \mathrm{C}$, Leu20 unchanged; base pairs 935-936 CG $\rightarrow$ GC, Leu237 unchanged, Val238 to Leu238; base pair 1,162 T $\rightarrow$ C, Phe313 to Ser313; base pair $1,245 \mathrm{~T} \rightarrow \mathrm{C}$, Ser341 to Pro341. Confirmation of the identity of both receptors is consistent with previous data that HUVEC-derived mRNA confers thrombin-responsiveness when injected into Xenopus oocytes (28) and that cultured HUVECs display intracytoplasmic calcium flux when stimulated with the synthetic peptide ligand (7).

To further evaluate the single nucleotide discrepancies, the radiolabeled 1,280-bp BamHI fragment was used to rescreen the HUVEC cDNA library, with the subsequent identification of four overlapping inserts. A 2.3-kb insert from one such phage (TR4-1) was subcloned into M13mp18 for sequence analysis. Base pair positions $282,1,162$, and 1,245 were identical to the previously published sequence, although the presence of the CG transversion (base pair 935-936) was confirmed. An additional $111 \mathrm{bp}$ of $5^{\prime}$ sequence was also identified and is displayed in Fig. $1 B$. This sequence contains no additional initiator methionine sequences (ATG) and, combined with the previously identified $224 \mathrm{bp}$ of $5^{\prime}$ sequence, confirms the presence of a $5^{\prime}$-untranslated region of $>300 \mathrm{bp}$. The significance of such long regions has been previously discussed (27).

Stable expression in $\mathrm{CHO}$ cells. PMT2-TR and PMT2-WT were used to transfect $\mathrm{CHO}$ cells as outlined above, and resistant colonies were initially screened for $\alpha$-thrombin responsiveness by microspectrofluorimetry. One such clone (designated CHO-17), which displayed the most consistent response, was further expanded and used for more extensive functional evaluation. Fig. $2 \mathrm{~A}$ illustrates typical $\left[\mathrm{Ca}^{2+}\right]_{\mathrm{i}}$ transients elicited by various concentrations of $\alpha$-thrombin. Higher agonist concentrations evoked immediate elevation of $\left[\mathrm{Ca}^{2+}\right]_{i}$ whereas delayed and more slowly developing responses were observed with lower concentrations of $\alpha$-thrombin. These responses exhibited homologous desensitization to $\alpha$-thrombin such that, at 10 and $30 \mathrm{~min}$ after initial activation, undetectable responses were seen with repeat stimulation (data not shown). These data are similar to those previously observed in various thrombin-responsive cell lines $(8,29)$. Similar $\left[\mathrm{Ca}^{2+}\right]_{i}$ transients were observed with a 14-mer peptide ligand that, in contrast to $\alpha$ thrombin, showed only short-term homologous desensitization. After washout of the ligand, $\left[\mathrm{Ca}^{2+}\right]_{\mathrm{i}}$ responses reappeared within $10 \mathrm{~min}$ and at $30 \mathrm{~min}$ were indistinguishable from the primary response (Fig. $2 \mathrm{~B}$ ). This latter response is qualitatively similar to that previously described in HEL cells, although the rate of full recovery is more rapid (8). On the basis of these responses, concentrations of $10 \mathrm{nM} \alpha$-thrombin and $20 \mu \mathrm{M}$ peptide ligand were used for further experiments. No responses to either $\alpha$-thrombin or peptide ligand were observed in mocktransfected $\mathrm{CHO}$ cell controls.

Generation of a recombinant protein and antibody. A 483bp fragment encompassing amino acid residues 1-160 of the TR was isolated by PCR using primers 512/603 and subcloned into the expression plasmid pGEX2T. Sequence analysis in M13mp18 confirmed the identity of the PCR product. After transformation into $E$. coli, an inducible band of the appropriate molecular weight $\left(\sim 45,000 M_{\mathrm{r}}\right.$ : GST carrier $[27,500]$ and recombinant TR $[18,000])$ was observed by $8 \%$ SDSPAGE (not shown). The specificity of the product was further confirmed by immunoblot analysis using a polyclonal antibody developed to a previously isolated GST recombinant protein (not shown) (30). The recombinant protein was then affin-
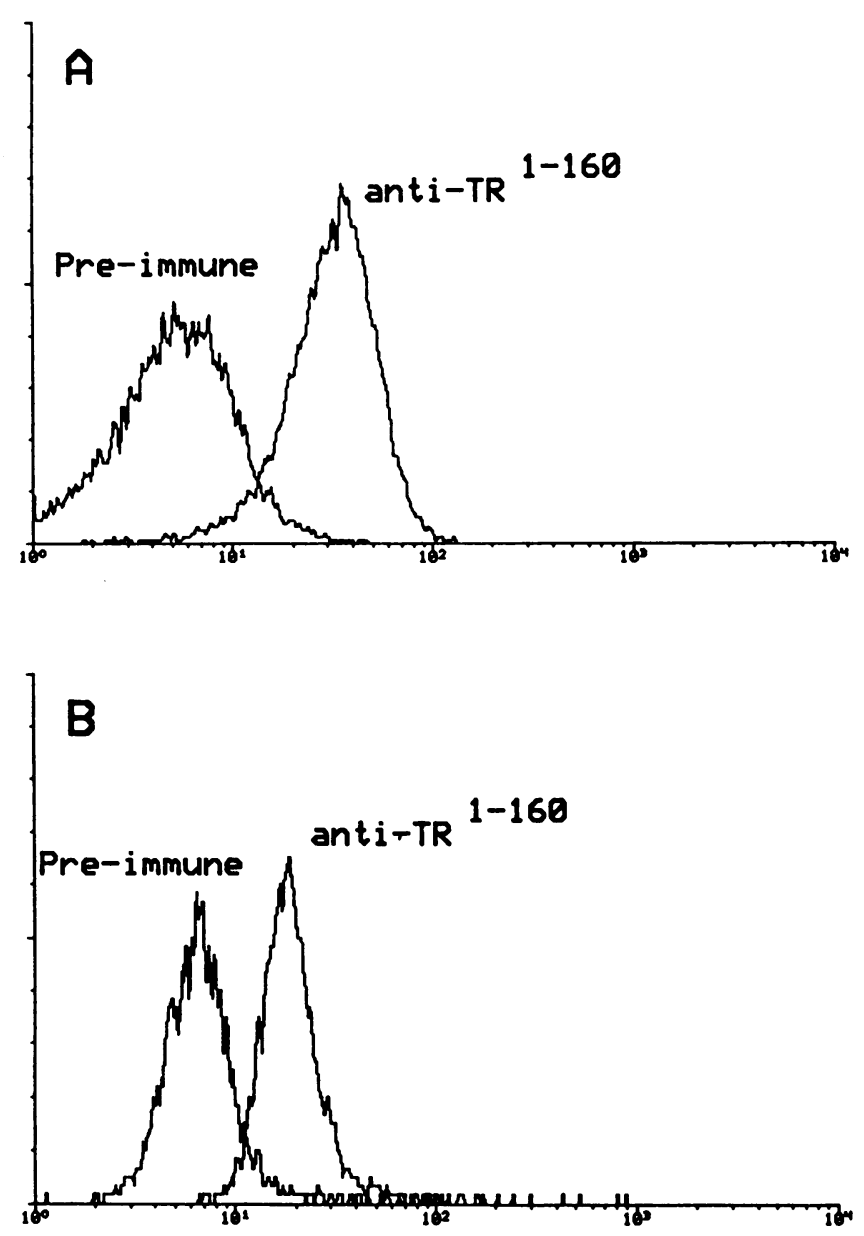

Figure 3. Flow cytometric analysis using platelets $(A)$ or transfected CHO cells $(C H O-17)(B)$. $(A)$ Gel-filtered platelets were prepared from human volunteers and resuspended in TSE buffer to a final concentration of $3.5-4 \times 10^{8} / \mathrm{ml} .400 \mu \mathrm{l}$ was incubated with preimmune IgG $(100 \mu \mathrm{g} / \mathrm{ml})$ or anti-TR ${ }^{1-160}(100 \mu \mathrm{g} / \mathrm{ml}) \mathrm{IgG}$ for $20 \mathrm{~min}$ at $25^{\circ} \mathrm{C}$, washed, and incubated with a FITC-conjugated goat anti-rabbit $\mathrm{F}\left(\mathrm{ab}^{\prime}\right)_{2}$ at a dilution of 1:100 for $30 \mathrm{~min}$ before analysis. (B) CHO-17 cells were grown in suspension culture and diluted to a final concentration of $2 \times 10^{6}$ cells $/ \mathrm{ml} .400 \mu \mathrm{l}$ was then incubated with preimmune $\operatorname{IgG}(100 \mu \mathrm{g} / \mathrm{ml})$ or anti-TR ${ }^{1-160}(100 \mu \mathrm{g} / \mathrm{ml})$ and analyzed as described above. Approximately $5 \times 10^{4}$ total cells were used for final flow cytometric analysis in both $(A)$ and $(B)$. 
ity purified from total bacterial lysates as outlined above, electroeluted, and used for the generation of a specific rabbit polyclonal antibody (anti-TR ${ }^{1-160}$ ).

Documentation that the antibody recognized normally expressed TR was confirmed using platelets, transfected $\mathrm{CHO}$ cells, and HUVECs. Platelets and transfected CHO cells expressing the TR were incubated with anti-TR ${ }^{1-160}$ or preimmune IgG and studied by flow cytometric analysis. Specific binding to platelets and $\mathrm{CHO}-17$ cells was evident (Fig. 3); no demonstrable binding was evident using IgG purified from preimmune rabbits. Likewise, endothelial cells were grown on coverslips, fixed, and stained with anti-TR ${ }^{1-160}$. As shown in Fig. 4, specific staining is observed with anti-TR ${ }^{1-160}$ whereas no immunofluorescence is observed with preimmune control $\mathrm{IgG}$, demonstrating that the TR is normally expressed on cultured endothelial cells. To confirm that anti-TR ${ }^{1-160}$ does not result in TR internalization, vital staining was completed on live endothelial cells incubated at either 25 or $4^{\circ} \mathrm{C}$ for $60 \mathrm{~min}$ with anti-TR ${ }^{1-160}$ before adding the FITC-labeled antibody. A similar pattern and intensity of immunofluorescence was observed under both conditions. Furthermore, incubation of the labeled cells with trypsin resulted in dramatic signal attenuation, supporting a surface location for the antibody-receptor complexes.

Functional effects of anti-TR $R^{1-160}$ and anti-TR $R^{34-52}$ on $\left[\mathrm{Ca}^{2+}\right]_{i}$. Activation-dependent responses to both $\alpha$-thrombin and peptide ligand were subsequently evaluated in transfected $\mathrm{CHO}$ cells, endothelial cells, and platelets using anti-TR ${ }^{34-52}$ and anti-TR ${ }^{1-160}$. Preincubation of $\mathrm{CHO}-17$ cells with either anti-TR ${ }^{1-160}$ IgG or anti-TR ${ }^{34-52}$ IgG at $450-475 \mu \mathrm{g} / \mathrm{ml}$ completely abrogated $\alpha$-thrombin-induced $\left[\mathrm{Ca}^{2+}\right]_{\mathrm{i}}$ transients (Fig. 5 ), but only anti-TR ${ }^{1-160}$ inhibited $\left[\mathrm{Ca}^{2+}\right]_{\mathrm{i}}$ transients induced by the 14-amino acid peptide ligand. Preincubation of cells with preimmune IgG had no effect on either $\alpha$-thrombin- or peptide ligand-induced receptor activation. To further characterize these effects, a dose-response curve for inhibition by antiTR $^{1-160}$ was performed (Fig. 6). Anti-TR ${ }^{1-160}$ inhibited $\sim 50 \%$ of the $\left[\mathrm{Ca}^{2+}\right]_{i}$ responses induced by both $\alpha$-thrombin and peptide ligand at approximately equivalent concentrations $\left(\mathrm{EC}_{50}\right.$ $\sim 90 \mu \mathrm{g} / \mathrm{ml}$ ).

To extend the observations made in transfected $\mathrm{CHO}$ cells, changes in cytosolic calcium concentration were further stud-
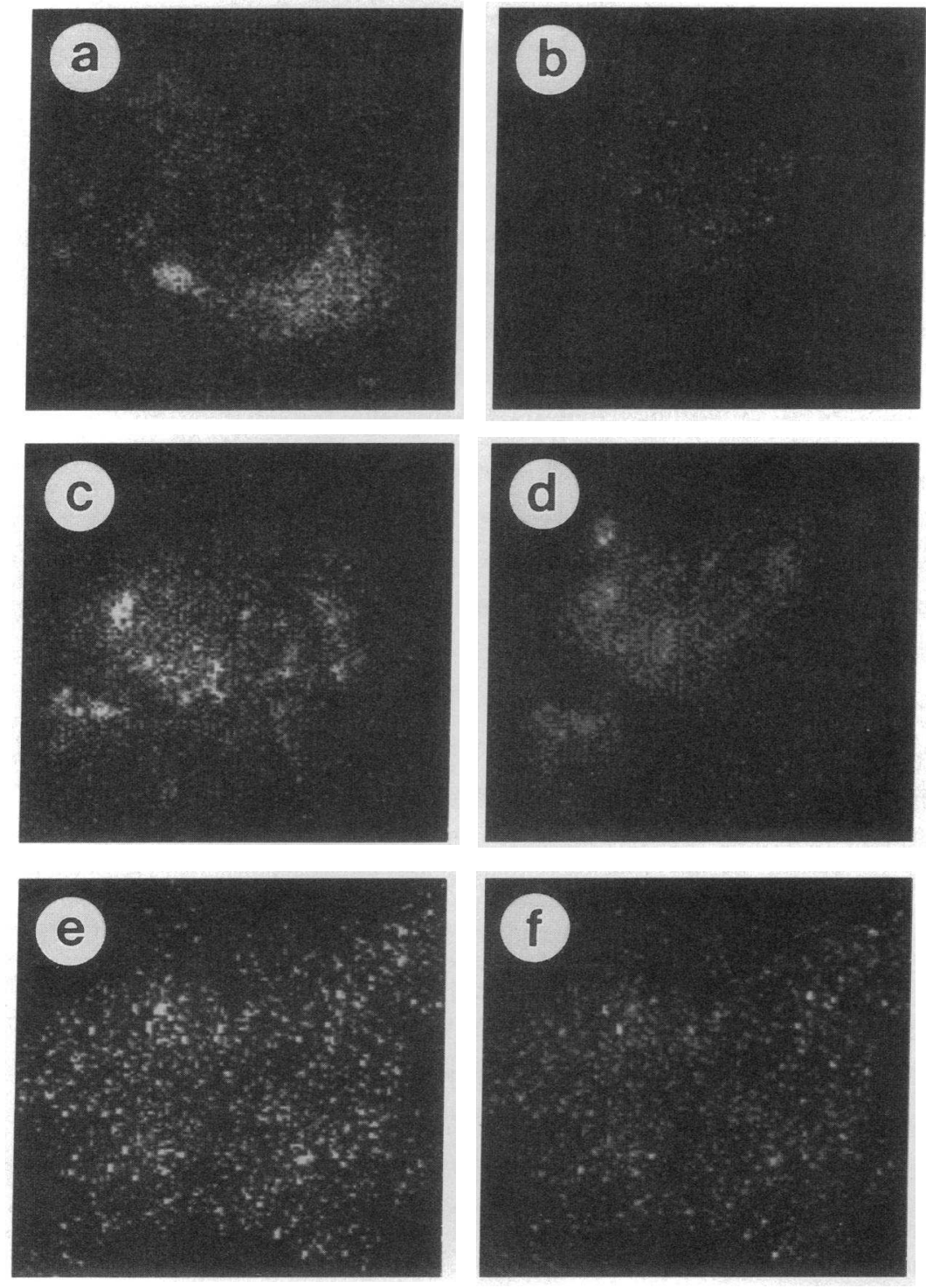

Figure 4. Immunocytochemistry of endothelial cell TR using anti-TR ${ }^{1-160}$. HUVECs were propagated on gelatin-coated glass coverslips as described above. In all situations the secondary antibody was a FITC-conjugated goat anti-rabbit IgG at a 1:200 dilution. Fluorescence intensity is depicted by the bar graph, white being the most intense. $(800 \times)$. Fixed cells were incubated with (a) $450 \mu \mathrm{g} / \mathrm{ml}$ anti-TR ${ }^{1-160} \mathrm{IgG}$ or (b) $450 \mu \mathrm{g} / \mathrm{ml}$ preimmune rabbit IgG. Vital staining of live cells was completed with (c) $450 \mu \mathrm{g} / \mathrm{ml}$ anti-TR ${ }^{1-160}$ for $60 \mathrm{~min}$ at $25^{\circ} \mathrm{C}$ or $(e) 450 \mu \mathrm{g} / \mathrm{ml}$ anti-TR ${ }^{1-160}$ for $60 \mathrm{~min}$ at $4^{\circ} \mathrm{C}$. In $d$ and $f$, cells from $c$ and $e$, respectively, were incubated with $500 \mathrm{U} / \mathrm{ml}$ trypsin for $4 \mathrm{~min}$ and the identical cell was reimaged. Note that the punctate fluorescence pattern observed in $c$ and $e$ has essentially disappeared after incubation with trypsin ( $d$ and $f$ ). These results demonstrate that the TR is normally expressed in cultured endothelial cells and that anti-TR ${ }^{1-160}$ does not result in clearance of the receptor from the cell surface. 

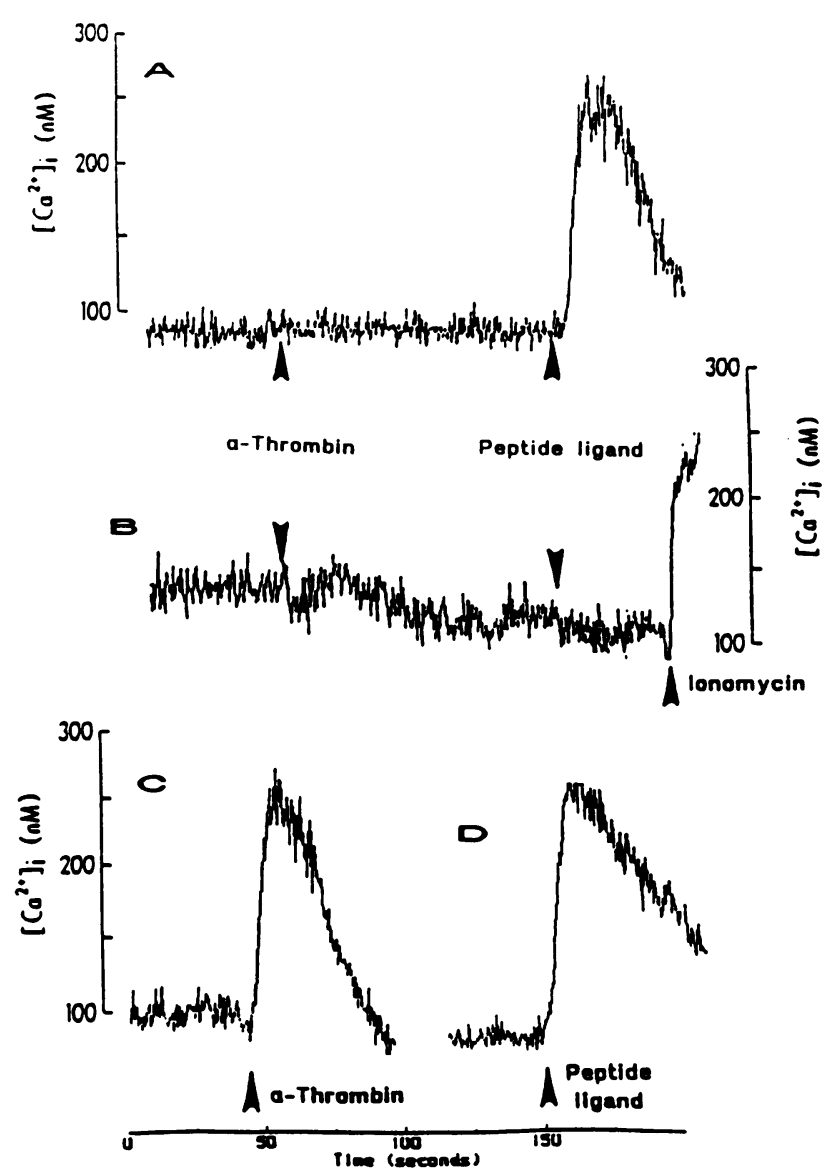

Figure 5. Effect of anti-TR ${ }^{1-160}$, anti-TR ${ }^{34-52}$, or preimmune IgG (see text) on peptide ligand- and $\alpha$-thrombin-induced receptor activation. Microspectrofluorimetry of $\mathrm{CHO}-17$ cells was performed as described in Fig. 2. Fura 2-loaded CHO-17 cells were incubated with $(A) \sim 450$ $\mu \mathrm{g} / \mathrm{ml}$ anti-TR ${ }^{34-52} \mathrm{IgG},(B) \sim 475 \mu \mathrm{g} / \mathrm{ml}$ anti-TR ${ }^{1-160} \mathrm{IgG}$, or $(C$ and D) $\sim 750 \mu \mathrm{g} / \mathrm{ml}$ of preimmune IgG for $20 \mathrm{~min}$ at $25^{\circ} \mathrm{C}$, and subsequently stimulated with $10 \mathrm{nM} \alpha$-thrombin or $20 \mu \mathrm{M} \mathrm{TR}^{42-55}$ peptide ligand. Whereas preincubation of cells with anti-TR ${ }^{34-52}$ abolished only $\alpha$-thrombin-mediated cell response, preincubation with anti$\mathrm{TR}^{1-160}$ abrogated receptor activation by both $\alpha$-thrombin and peptide ligand. No inhibitory effects were seen with either agonist using preimmune IgG. For nonreactive cells $(B)$, viability was confirmed by demonstrating $\left[\mathrm{Ca}^{2+}\right]_{\mathrm{i}}$ transients in response to $1 \mu \mathrm{M}$ ionomycin.

ied in cultured HUVECs and platelets. As with $\mathrm{CHO}-17$ cells, anti-TR ${ }^{1-160}$ abolished $\left[\mathrm{Ca}^{2+}\right]_{\mathrm{i}}$ transients in response to peptide ligand in HUVECs (Fig. $7 \mathrm{~B}$ ) and platelets (Fig. $8 \mathrm{~B}$ ) at approximately similar concentrations of $225 \mu \mathrm{g} / \mathrm{ml}$. In sharp contrast to results observed in CHO-17 cells, however, anti-TR ${ }^{1-160}$ did not abrogate the response of HUVECs or platelets to $10 \mathrm{nM}$ $\alpha$-thrombin. Rather, both cell types displayed a delayed but sustained elevation in $\left[\mathrm{Ca}^{2+}\right]_{\mathrm{i}}$ transients, evident despite increasing concentrations of the antibody (Figs. $7 A$ and $8 C$ ).

Platelet aggregation. Anti-TR ${ }^{34-52}$ IgG dramatically inhibited platelet aggregation induced by low concentrations of $\alpha$ thrombin $(1 \mathrm{nM})$, although some shape change remained (Fig. $9 A$ ). Increasing the concentration of $\alpha$-thrombin overcame the inhibition. Similar data were obtained with $\mathrm{F}\left(\mathrm{ab}^{\prime}\right)_{2}$ fragments of anti-TR ${ }^{34-52}$, with $50 \%$ inhibition of aggregation induced by 1 $\mathrm{nM} \alpha$-thrombin requiring between 63 and $125 \mu \mathrm{g} / \mathrm{ml}$ of the

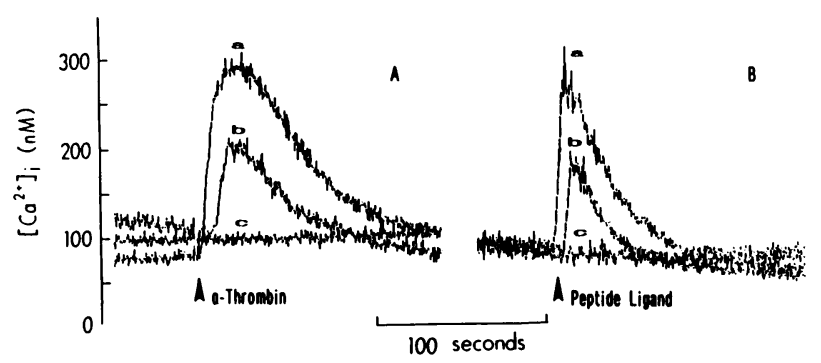

Figure 6. Dose-inhibition curve for anti-TR ${ }^{1-160}$ using $\alpha$-thrombin $(A)$ or $\mathrm{TR}^{42-55}$ peptide ligand $(B)$. ( $A$ ) Fura 2-loaded $\mathrm{CHO}-17$ cells were incubated for $20 \mathrm{~min}$ at $25^{\circ} \mathrm{C}$ with anti-TR ${ }^{1-160}$ at concentrations of $225 \mu \mathrm{g} / \mathrm{ml}$ (curve $c$ ), $90 \mu \mathrm{g} / \mathrm{ml}$ (curve $b$ ), or PBS alone (curve $a$ ) before stimulation with $10 \mathrm{nM} \alpha$-thrombin. (B) Dose-inhibition curves using the peptide ligand. Experiments are identical to those performed in $A$, except cells were stimulated with $20 \mu \mathrm{M}$ peptide ligand. These data represent the average of three similar experiments.

$\mathrm{F}\left(\mathrm{ab}^{\prime}\right)_{2}$ (data not shown). Anti-TR ${ }^{34-52} \mathrm{IgG}$ had no significant effect on platelet aggregation induced by limiting concentrations of peptide ligand $(6.2 \mu \mathrm{M})$ in citrated PRP at concentrations up to $500 \mu \mathrm{g} / \mathrm{ml}$, a concentration that was very effective in inhibiting $\alpha$-thrombin-induced aggregation (Fig. $9 B$ ). Likewise, anti-TR ${ }^{34-52} F\left(a b^{\prime}\right)_{2}$ failed to inhibit peptide ligand-induced platelet aggregation at concentrations up to $340 \mu \mathrm{g} / \mathrm{ml}$ (data not shown). In contrast, inhibitory effects to anti-TR ${ }^{1-160}$ $\mathrm{F}\left(\mathrm{ab}^{\prime}\right)_{2}$ fragments were seen when platelets were activated by either $\alpha$-thrombin or the peptide ligand. Platelet aggregation to $\alpha$-thrombin was inhibited in a dose-dependent fashion, although some shape change remained (Fig. 10). Similar inhibitory effects were seen using peptide ligand as agonist. No inhibitory effects were seen when platelets were activated by ADP, confirming the specificity of the antibody for aggregation by $\alpha$-thrombin and the peptide ligand agonist (Fig. 10).

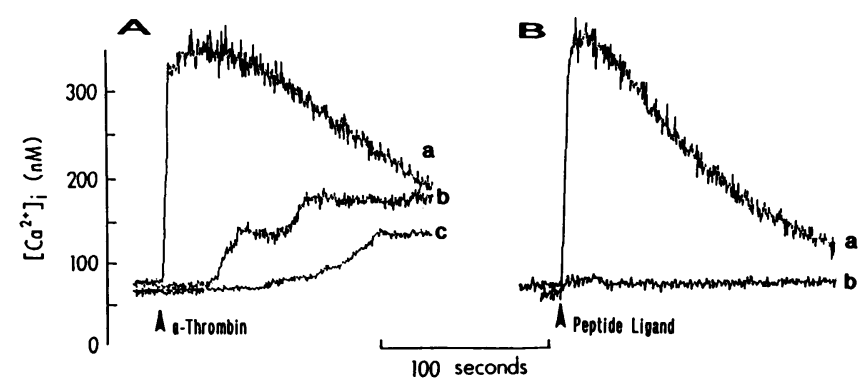

Figure 7. Microspectrofluorimetry using endothelial cells activated by (A) $10 \mathrm{nM} \alpha$-thrombin or $(B) 20 \mu \mathrm{M} \mathrm{TR}^{42-55}$ peptide ligand after incubation with anti-TR ${ }^{1-160}$ or control antibody. HUVECs were propagated on gelatin-coated coverslips in complete medium (see above), serum starved for $18 \mathrm{~h}$, and subsequently loaded with $2.5 \mu \mathrm{M}$ fura 2/AM for $60 \mathrm{~min}$ at $37^{\circ} \mathrm{C}$. $(A)$ Cells were incubated for $20 \mathrm{~min}$ at $25^{\circ} \mathrm{C}$ with $450 \mu \mathrm{g} / \mathrm{ml}$ preimmune IgG (curve $a$ ), $225 \mu \mathrm{g} / \mathrm{ml}$ anti$\mathrm{TR}^{1-160}$ (curve $b$ ), or $450 \mu \mathrm{g} / \mathrm{ml}$ anti-TR ${ }^{1-160}$ (curve $c$ ). (B) HUVECs were incubated for $20 \mathrm{~min}$ at $25^{\circ} \mathrm{C}$ with $450 \mu \mathrm{g} / \mathrm{ml}$ preimmune antibody (curve $a$ ) or $225 \mu \mathrm{g} / \mathrm{ml}$ anti-TR ${ }^{1-160}$ (curve $b$ ) before activation by peptide ligand. Abrogation of peptide ligand-mediated $\left[\mathrm{Ca}^{2+}\right]_{i}$ transients is evident, although a delayed but sustained response is seen with $\alpha$-thrombin. Tracings are representative of three identical experiments. 

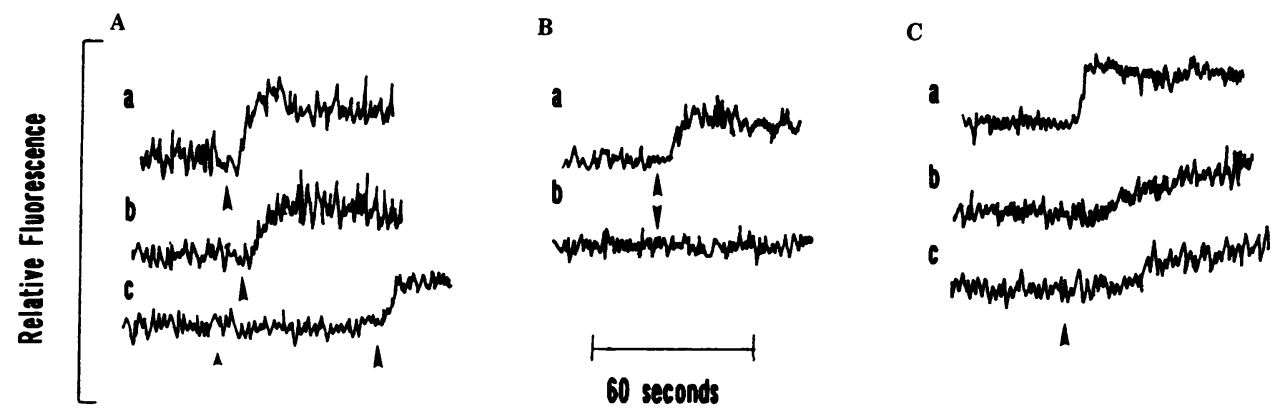

Figure 8. Activation-dependent $\left[\mathrm{Ca}^{2+}\right]_{i}$ transients in platelets. GFPs were prepared as described in Methods and loaded with $3 \mu \mathrm{M}$ fura $2 /$ $\mathrm{AM}$ for $60 \mathrm{~min}$ at $37^{\circ} \mathrm{C} .1 \mathrm{ml}$ of GFP $\left(1.5 \times 10^{8}\right.$ platelets $\left./ \mathrm{ml}\right)$ was continuously stirred in a $1.5-\mathrm{ml} \mathrm{cu}$ vette at $37^{\circ} \mathrm{C}$ for all experiments. $(A)$ Representative tracings after activation with $10 \mathrm{nM} \alpha$-thrombin (curve $a$ ), $20 \mu \mathrm{M} \mathrm{TR}^{42-55}$ peptide ligand (curve $b$ ), or $20 \mu \mathrm{M}$ of the control peptide in which the se-

quence of the first two amino acids was reversed (T1C2, left arrow), followed by $20 \mu \mathrm{M}$ peptide ligand (right arrow) (curve $c$ ). (B) GFP was incubated for $20 \mathrm{~min}$ at $25^{\circ} \mathrm{C}$ with $320 \mu \mathrm{g} / \mathrm{ml}$ preimmune $\mathrm{F}\left(\mathrm{ab}^{\prime}\right)_{2}$ antibody (curve $a$ ) or $250 \mu \mathrm{g} / \mathrm{ml}$ anti-TR ${ }^{1-160} \mathrm{~F}\left(\mathrm{ab}^{\prime}\right)_{2}$ (curve $b$ ) before activation by $20 \mu \mathrm{M}$ peptide ligand. (C) GFP were incubated for $20 \mathrm{~min}$ at $25^{\circ} \mathrm{C}$ with $320 \mu \mathrm{g} / \mathrm{ml} \mathrm{preimmune} \mathrm{F}\left(\mathrm{ab}^{\prime}\right)_{2}$ serum (curve $a$ ), $100 \mu \mathrm{g} / \mathrm{ml}$ anti-TR ${ }^{1-160}$ $\mathrm{F}\left(\mathrm{ab}^{\prime}\right)_{2}$ (curve $b$ ), or $300 \mu \mathrm{g} / \mathrm{ml}$ anti-TR ${ }^{1-160} \mathrm{~F}\left(\mathrm{ab}^{\prime}\right)_{2}$ (curve $c$ ) before activation by $10 \mathrm{nM} \alpha$-thrombin. Peptide-induced intracytoplasmic transients are abolished whereas delayed but persistent responses are evident with $\alpha$-thrombin. Tracings are representative of duplicate sets of experiments.

\section{Discussion}

A model for the activation of this TR by $\alpha$-thrombin has been postulated. Accordingly, thrombin cleaves its receptor's amino-terminal extension, thereby creating a tethered ligand that presumably activates the receptor by binding to an as yet unidentified downstream recognition site (4). Thrombin interacts with the TR at least in part through the receptor's acidic hirudin-like domain, which is located adjacent to the thrombin cleavage site $(31,32)$. The importance of the hirudin-like domain is supported by mutagenesis studies involving this region of the receptor (32) and by the inhibitory effect of hirudin-like domain peptides that bind to thrombin, presumably through the latter's anion-binding exosite (31). More recently, polyclonal (33) and monoclonal antibodies (34) directed against synthetic peptides from these regions of the receptor have been shown to inhibit thrombin-induced platelet activation. Anti$\mathrm{TR}^{34-52}$ is directed against a somewhat different peptide from the thrombin cleavage site and similarly inhibits $\alpha$-thrombininduced platelet activation and aggregation. Neither of the previously described antibodies nor anti-TR ${ }^{34-52}$, however, inhibit platelet activation or aggregation induced by synthetic peptide ligands modeled on the new $\mathrm{NH}_{2}$ terminus produced by thrombin cleavage.
To date little is known about the mechanism by which the tethered ligand mediates receptor activation and, in particular, the proposed site on the remainder of the receptor to which it binds. Anti-TR ${ }^{1-160}$, directed against a recombinant protein containing the $\mathrm{NH}_{2}$-terminal extension of the TR, up to and including the second transmembrane domain, inhibited both $\alpha$-thrombin- and peptide ligand-mediated receptor activation in a heterologous cell line expressing the functionally active $\mathrm{TR}$, in endothelial cells, and platelets. Because the recognition sequence for this antibody spans both the thrombin cleavage site and the hirudin-like domain, its inhibitory effect on thrombin-mediated receptor activation is not unexpected and is consistent with functional data using previously developed antibodies $(26,33,34)$. Its ability to inhibit peptide ligand-induced $\left[\mathrm{Ca}^{2+}\right]_{\mathrm{i}}$ transients, however, was unanticipated. The antibody also dramatically inhibited peptide ligand-induced platelet aggregation, although some shape change persisted, perhaps because of release of small amounts of calcium below the sensitivity of the detection system. The ability of the antibody to inhibit peptide ligand-induced activation further suggests that a recognition sequence ultimately critical for receptor activation is contained within the portion of the receptor recognized by anti-TR ${ }^{1-160}$. Alternatively, the antibody is exerting its effect by inhibiting conformational constraints necessary for peptide li-
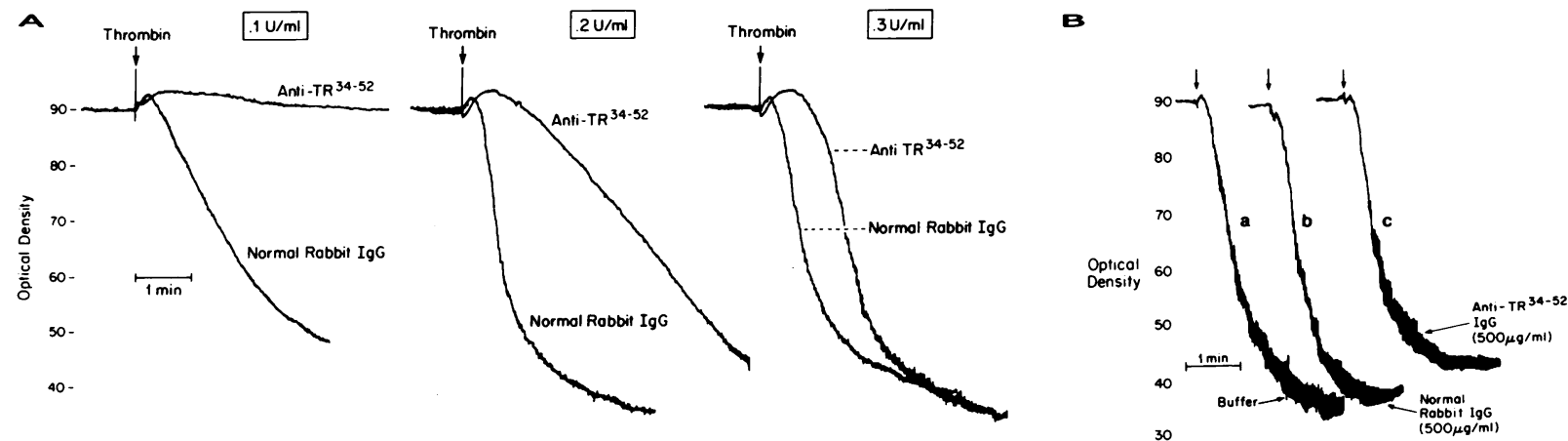

Figure 9. Effect of anti-TR ${ }^{34-52}$ on platelet aggregation to $(A)$ thrombin or $(B) \mathrm{TR}^{42-52}$ peptide ligand. $(A)$ Platelets were gel filtered into the HBMT buffer containing $2 \mathrm{mM} \mathrm{MgCl}_{2}$, and then $0.4 \mathrm{ml}$ of GFP $\left(3 \times 10^{8}\right.$ platelets $\left./ \mathrm{ml}\right)$ was incubated with $250 \mu \mathrm{g} / \mathrm{ml}$ of normal rabbit IgG or anti-TR $\mathrm{m}^{34-52}$ $\mathrm{IgG}$ for $\geq 15 \mathrm{~min}$ at $22^{\circ} \mathrm{C}$. Aggregation was initiated with the indicated concentrations of purified $\alpha$-thrombin. $(B) \mathrm{Citrated} P R P\left(3 \times 10^{8}\right.$ platelets $/ \mathrm{ml}$ ) was incubated with buffer (curve $a$ ), anti-TR ${ }^{34-52} \operatorname{IgG}(500 \mu \mathrm{g} / \mathrm{ml})$ (curve $b$ ), or normal rabbit IgG $(500 \mu \mathrm{g} / \mathrm{ml})(\mathrm{curve} c)$ for $\geq 15 \mathrm{~min}$ at $22^{\circ} \mathrm{C}$, and then aggregation was initiated with peptide ligand $\left(6.2 \mu \mathrm{M}\right.$ final concentration, arrows). Anti-TR ${ }^{34-52}$ inhibited platelet aggregation to $\alpha$-thrombin but had no effect on peptide ligand-induced aggregation. 
A

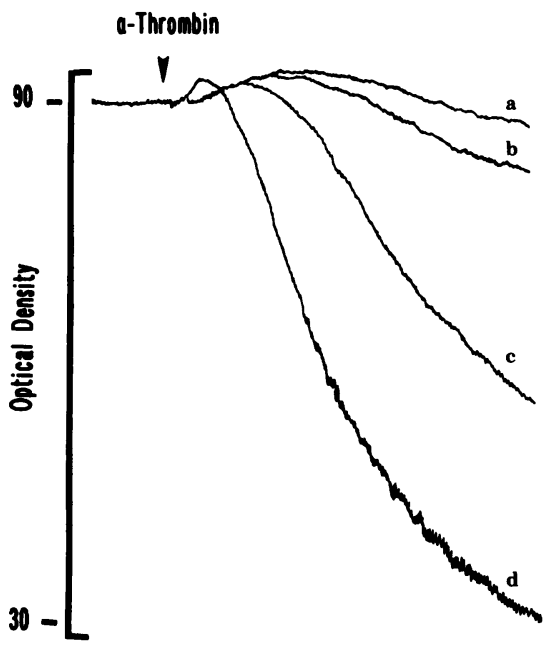

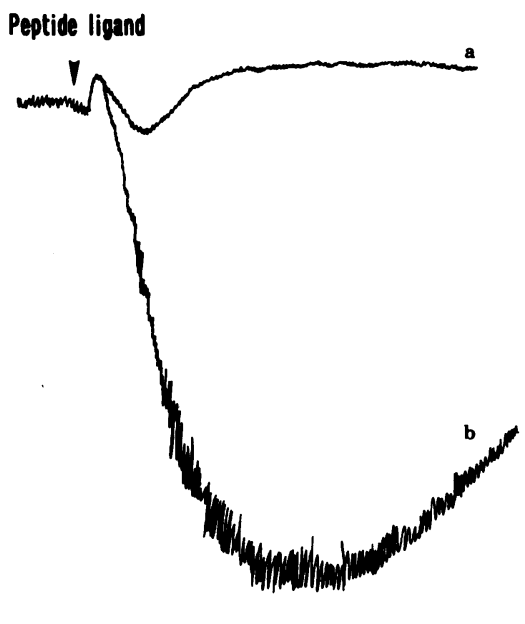

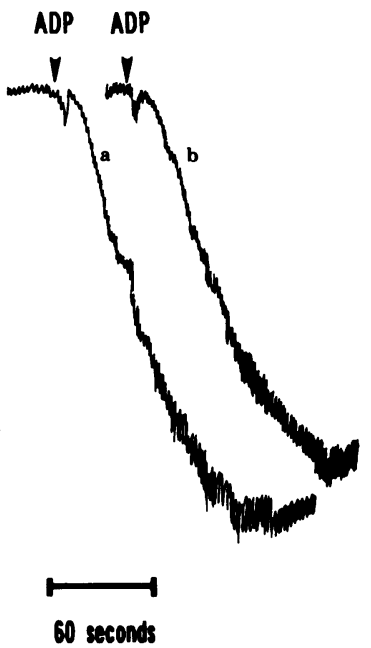

Figure 10. Platelet aggregation inhibitory effects of anti-TR ${ }^{1-160}$ to both $(A) 1 \mathrm{nM} \alpha$-thrombin and $(B) 10 \mu \mathrm{M}$ TR ${ }^{42-52}$ peptide ligand. Antibody incubations were performed at $25^{\circ} \mathrm{C}$ for $20 \mathrm{~min}$. $(A) \mathrm{GFP}$ was prepared as described in Methods and resuspended to $2.8 \times 10^{8}$ platelets $/ \mathrm{ml}$. $0.45 \mathrm{ml} \mathrm{GFP}$ was then transferred to a platelet aggregometer for analysis. Dose-dependent inhibition of platelet aggregation using anti-TR ${ }^{1-160}$ $\mathrm{F}\left(\mathrm{ab}^{\prime}\right)_{2}$ at $30 \mu \mathrm{g} / \mathrm{ml}$ (curve $c$ ), $100 \mu \mathrm{g} / \mathrm{ml}$ (curve $b$ ), or $150 \mu \mathrm{g} / \mathrm{ml}$ (curve $a$ ) is evident. Curve $d$ represents activation response after incubation with control preimmune $\mathrm{F}\left(\mathrm{ab}^{\prime}\right)_{2}$ antibody at $150 \mu \mathrm{g} / \mathrm{ml}$. (B) Citrated PRP $\left(3 \times 10^{8}\right.$ platelets $\left./ \mathrm{ml}, \mathrm{pH} 7.6,0.45 \mathrm{ml}\right)$ was prepared and incubated with $310 \mu \mathrm{g} / \mathrm{ml}$ anti-TR ${ }^{1-160} \mathrm{~F}\left(\mathrm{ab}^{\prime}\right)_{2}$ (curve $a$ ) or $340 \mu \mathrm{g} / \mathrm{ml}$ preimmune $\mathrm{F}\left(\mathrm{ab}^{\prime}\right)_{2}$ antibody (curve $b$ ). Aggregations were initiated by incubation with peptide ligand. Anti-TR ${ }^{1-160}$ profoundly inhibited aggregation, but platelet shape change was not abolished. (C) Normal aggregation of PRP to ADP is evident using $340 \mu \mathrm{g} / \mathrm{ml}$ preimmune $\mathrm{F}\left(\mathrm{ab}^{\prime}\right)_{2}$ antibody (curve $a$ ) or $310 \mu \mathrm{g} / \mathrm{ml}$ anti-TR ${ }^{1-160} \mathrm{~F}\left(\mathrm{ab}^{\prime}\right)_{2}$ (curve $b$ ), confirming the specificity of anti-TR ${ }^{1-160}$ for ligand- and $\alpha$-thrombin-induced platelet aggregation.

gand-mediated activation or perhaps by limiting ligand accessibility by inducing the redistribution of receptors.

Presumably, the peptide ligand exerts its effect by binding to an unidentified site within the body of the receptor. If anti$\mathrm{TR}^{1-160}$ inhibits peptide ligand-induced activation by preventing the binding of the peptide to the receptor, this binding site must be contained within the antigenic determinants of the antibody (residues $1-160$ ). Since anti-TR ${ }^{1-160}$ is unlikely to react with the transmembrane domains (TMS I and II) or the first intracytoplasmic (IC I) loop, the site responsible for its effect on peptide ligand-induced activation is most likely in the $\mathrm{NH}_{2}$-terminal extension of the receptor (amino acid residues 1-99). Moreover, the peptide-binding site is most likely distal to the thrombin cleavage site (LDPR/S, amino acids 41-42), thereby suggesting that the crucial site for peptide ligand-induced receptor activation may be further localized to residues Ser42-Ser99. Previous studies demonstrated that a polyclonal antibody directed against a peptide encompassing amino acid residues Tyr52-Tyr69, representing the hirudin-like domain (33), did not affect peptide ligand-mediated activation, although inhibition to $\alpha$-thrombin was evident. Moreover, previous mutagenesis studies involving the hirudin-like domain of the TR failed to demonstrate any effect on peptide ligand-mediated receptor activation (32). Extrapolation from these data would further suggest that a sequence or sequences between amino acids Arg70 and Ser99 is involved in peptide binding. As indicated above, however, the antibody may inhibit peptide ligand-induced activation by other mechanisms, including cooperative effects with other regions of the receptor.

Cellular responses to $\alpha$-thrombin have been extensively studied in a number of diverse model systems, with a suggestion, but no proof, of the presence of multiple receptors and/or signaling pathways $(29,35-37)$. In fibroblasts (9) and vascular smooth muscle cells (37), $\alpha$-thrombin-induced mitogenic pathway(s) appear to be distinct from those associated with elevations of $\left[\mathrm{Ca}^{2+}\right]_{\mathrm{i}}$ transients. Dual activation pathways and/ or coupling mechanisms have been described both in platelets $(35,38,39)$ and in cultured human endothelial cells $(3)$, possibly related to distinct G-proteins as determined by sensitivity to Bordetella pertussis toxin $(38,40)$. Despite the recent identification of this TR, and the availability of activation peptide ligands and both polyclonal and monoclonal antibodies, the mechanism(s) of $\alpha$-thrombin-mediated activation pathways are yet incompletely resolved $(6,34-40)$. The data presented here are consistent with these previous observations of $\alpha$ thrombin-mediated dual activation and/of receptor pathways. Whereas $\left[\mathrm{Ca}^{2+}\right]_{i}$ transients in response to both peptide ligand and $\alpha$-thrombin were abolished in transfected $\mathrm{CHO}$ cells, the responses to $\alpha$-thrombin were more complex in platelets and HUVECs. Peptide-induced $\left[\mathrm{Ca}^{2+}\right]_{\mathrm{i}}$ transients were abolished in both cells, identical to the responses observed in CHO-TR cells, although delayed and sustained elevations in intracytoplasmic calcium release occurred when platelets and endothelial cells were activated by $\alpha$-thrombin. It is unlikely that this residual response is due to a competitive affinity advantage for $\alpha$-thrombin compared with anti-TR ${ }^{1-160}$ at the TR since identical concentrations of both reagents abolished the $\left[\mathrm{Ca}^{2+}\right]_{i}$ response in CHO-TR cells. Rather, these data suggest that an alternative receptor and/or coupling mechanism(s) for $\alpha$ thrombin activation exists in both HUVECs and platelets. Alternatively, the affinity of $\alpha$-thrombin for this receptor may be facilitated by interaction with other cell surface receptors in platelets and endothelial cells, a synergistic role that has been postulated for platelet glycoprotein Ib $\alpha(41)$. 


\section{Acknowledgments}

We thank Ms. Barbara Milano and Mrs. Shirley Murray for assistance in the preparation of this manuscript, Mr. James Simone for assistance with the flow cytometric analysis, and Dr. Jolyon Jesty for critical reading of the manuscript and insightful discussion. We also thank Dr. Ellinor Peerschke for helpful advice with the platelet intracytoplasmic calcium measurements and Dr. Edward Nord for the guidance and use of the spectrofluorometer. Ms. Lesley Scudder assisted with the platelet aggregation studies and Ms. Karen Springer assisted with the peptide synthesis. This paper is especially dedicated to Mrs. Juliet Ansara who will be surely missed by those who have experienced the pleasure of her loving support.

Supported in part by grants from the National Institutes of Health: HL-02431 (W. F. Bahou), DK-41573 and DK-26341 (M. S. Goligorsky), and HL-19278 (B. S. Coller); and the American Heart Association, New York State Affiliate (W. F. Bahou).

\section{References}

1. Fenton, J. 1988. Regulation of thrombin generation and functions. Semin Thromb. Hemostasis. 14:234-240.

2. Jamieson, G. 1988. The activation of platelets by thrombin: a model for activation by high and moderate affinity receptors. Prog. Clin. Biol. Res. 283:137-158.

3. Goligorsky, M., D. Menton, S. Laszlo, and H. Lum. 1990. Nature of thrombin-induced sustained increase in cytosolic calcium concentration in cultured endothelial cells. J. Biol. Chem. 264:16771-16775.

4. Vu, T.-K., D. Hung, V. Wheaton, and S. Coughlin. 1991. Molecular cloning of a functional thrombin receptor reveals a novel proteolytic mechanism of receptor activation. Cell. 64:1057-1068.

5. Dohlman, H., J. Thorner, M. Caron, and R. Lefkowitz. 1991. Model systems for the study of seven-transmembrane-segement receptors. Annu. Rev. Biochem. 60:653-688.

6. Seiler, S., H. Goldenbery, I. Michel, J. Hunt, and G. Zavoico. 1991. Multiple pathways of thrombin-induced platelet activation differentiated by desensitization and a thrombin exosite inhibitor. Biochem. Biophys. Res. Commun. 181:636-643.

7. Ngaiza, J., and E. Jaffe. 1991. A 14 amino acid peptide derived from the amino terminus of the cleaved thrombins receptor elevates intracellular calcium and stimulates prostacyclin production in human endothelial cells. Biochem. Biophys. Res. Commun. 179:1656-1661.

8. Brass, L. F. 1992. Homologous desensitization distinguishable roles for proteolysis and phosphorylation of HEL cell thrombin receptors. J. Biol. Chem. 267:6044-6050.

9. Vouret-Craviari, V., E. Van Obberghen-Schilling, U. V. Rasmussen, A. Pavirani, J.-P. Lecocq, and J. Pouyssegur. 1991. Synthetic alpha-thrombin receptor peptides activate $G$ protein-coupled signaling pathways but are unable to induce mitogenesis. Mol. Cell. Biol. 3:95-102.

10. Huang, R.-S., A. Sorisky, W. Church, E. Simms, and S. Rittenhouse 1991. "Thrombin" receptor-directed ligand accounts for activation by thrombin of platelet phospholipase $C$ and accumulation of 3-phosphorylated phosphoinositides. J. Biol. Chem. 266:18435-18448.

11. Seiler, S. M., I. M. Michel, and Fenton II, J. W. 1992. Involvement of the "tethered-ligand" receptor in thrombin inhibition of platelet adenylate cyclase. Biochem. Biophys. Res. Commun. 182:1296-1302.

12. Vassallo, Jr., R. R., T. Kieber-Emmons, K. Cichowski, and L. F. Brass. 1992. Structure-function relationships in the activation of platelet thrombin receptors by receptor-derived peptides. J. Biol. Chem. 267:6081-6085.

13. Coller, B., K. Springer, L. Scudder, and K. Norton. 1991. Studies of a peptide derived from a platelet thrombin receptor. Blood. 78:394. (Abstr.)

14. Ginsburg, D., R. Handin, D. Bonthron, T. Donlan, G. Bruns, S. Latt, and S. Orkin. 1985. Human von Willebrand factor (vWf): isolation of complementary (cDNA) clones and chromosomal localization. Science (Wash. DC). 228:14011416.

15. Feinberg, A., and B. Vogelstein. 1983. A technique for radiolabeling DNA restriction endonuclease fragments to high specific activity. Anal. Biochem. 132:6-12.

16. Maniatis, T., E. Fritsch, and E. Sambrook. 1982. Molecular Cloning: A Laboratory Manual. Cold Spring Harbor Laboratory, Cold Spring Harbor, New York.

17. Sanger, F., S. Nicklen, and A. Coulsen. 1977. DNA sequencing with chain terminating inhibitors. Proc. Natl. Acad. Sci. USA. 74:5463-5467.
18. Bahou, W., R. Ginsburg, R. Sikkink, R. Litwiller, and D. Fass. 1989. A monoclonal antibody to von Willebrand factor (vWf) inhibits FVIII binding. Localization of its antigenic determinant to a nonadecapeptide at the amino terminus of the mature vWf polypeptide. J. Clin. Invest. 84:56-61.

19. Bahou, W., A. Campbell, and M. Wicha. 1992. cDNA cloning and molecular characterization of MSE55: a novel human serum constituent protein that displays bone marrow stromal endothelial cell-specific expression. J. Biol. Chem. 267:13986-13992.

20. Ginsburg, D., B. A. Konkle, J. C. Gill, R. R. Montgomery, P. L. Bockenstedt, T. A. Johnson, and A. Y. Yang. 1989. Molecular basis of human von Willebrand disease: analysis of platelet von Willebrand factor mRNA. Proc. Natl. Acad. Sci. USA. 86:3723-3727.

21. Bonthron, D., R. Handin, R. Kaufman, L. Wasley, E. Orr, L. Mitsock, B. Ewenstein, J. Loscalzo, D. Ginsburg, and S. Orkin. 1986. Structure of pre-pro von Willebrand factor and its expression in heterologous cells. Nature (Lond.). 324:270-273.

22. Urlaub, G., and L. Chasin. 1980. Isolation of Chinese hamster cell mutants deficient in dihydrofulate reductase activity. Proc. Natl. Acad. Sci. USA. 77:4216-4220.

23. Chen, C., and H. Okayama. 1987. High efficiency transformation of mammalian cells by plasmid DNA. Mol. Cell. Biol. 7:2745-2752.

24. Grynkiewicz, G., M. Poenie, and R. Y. Tsien. 1985. A new generation of $\mathrm{Ca} 2+$ indicators with greatly improved fluorescence properties. J. Biol. Chem. 260:3440-3450. (Abstr.)

25. Coller, B. S., J. H. Beer, L. E. Scudder, and M. H. Steinberg. 1989. Collagen-platelet interactions: evidence for a direct interaction of collagen with platelet GPIa/Ila and an indirect interaction with platelet GPIIb/IIIa mediated by adhesive proteins. Blood. 74:182-192.

26. Norton, K. J., and B. S. Coller. 1992. A polyclonal antibody to a platelet thrombin receptor abolishes thrombin-induced platelet aggregation. Clin. Res. 40:171a. (Abstr.)

27. Kozak, M. 1989. An analysis of 5'-noncoding sequences from 699 vertegrate messenger RNA's. Nucleic Acids Res. 15:8125-8148.

28. Pipili-Synetos, E., M. C. Gershengorn, and E. A. Jaffe. 1990. Expression of functional thrombin receptors in Xenopus oocytes injected with human endothelial cell mRNA. Biochem. Biophys. Res. Commun. 171:913-919.

29. Jaffe, E., J. Grulich, B. Weksler, G. Hampel, and K. Watanabe. 1987. Correlation between thrombin-induced prostacyclin production and inositol triphosphate and cytosolic free calcium levels in cultured human endothelial cells. J. Biol. Chem. 262:8557-8565.

30. Bahou, W., C. Potter, K. Norton, and B. Coller. 1991. Molecular characterization of the VLA-2 I domain. Blood. 78:135. (Abstr)

31. Liu, L.-W., T.-K. Vu, C. Esmon, and S. Coughlin. 1991. The region of the thrombin receptor resembling hirudin binds to thrombin and alters enzyme specificity. J. Biol. Chem. 266:16977-16980.

32. Vu, T.-K., V. Wheaton, D. Hung, I. Charo, and S. Coughlin. 1991. Domains specifying thrombin-receptor interaction. Nature (Lond.). 353:674-677.

33. Hung, D. T., T.-K. H. Vu, V. I. Wheaton, K. Ishii, and S. R. Coughlin. 1992. Cloned platelet thrombin receptor is necessary for thrombin-induced platelet activation. J. Clin. Invest. 89:1350-1353.

34. Brass, L., R. Vassallo, E. Belmonte, M. Ahuja, K. Cichowski, and J. Hoxie. 1992. Structure and function of the human platelet thrombin receptor Studies using monoclonal antibodies directed against a defined domain within the receptor N terminus. J. Biol. Chem. 267:13795-13798.

35. McGowan, E., and T. Detwiller. 1987. Modified platelet responses to thrombin. Evidence for two types of receptors or coupling mechanisms. J. Biol. Chem. 261:739-746.

36. Chambard, J., S. Paris, G. L’Allemain, and J. Pouyssegur. 1987. Two growth factor signalling pathways in fibroblasts distinguished by pertussis toxin. Nature (Lond.). 326:800-803.

37. Weiss, R., and R. Nuccitelli. 1992. Inhibition of tyrosine phosphorylation prevents thrombin-induced mitogenesis, but not intracellular free calcium release. J. Biol. Chem. 267:5608-5613.

38. Brass, L., M. Laposata, H. Banga, and S. Rittenhouse. 1986. Regulation of the phosphoinositide hydrolysis pathway in thrombin-stimulated platelets by a pertussis toxin-sensitive guanine nucleotide-binding protein. Evaluation of its contribution to platelet activation and comparisons with the adenylate cyclase inhibitory protein $\mathrm{G}_{\mathrm{i}}$. J. Biol. Chem. 261:16838-16847.

39. Oberdisse, E., and E. Lapetina. 1987. GDP $_{B} S$ enhances the activation of phospholipase $\mathrm{C}$ caused by thrombin in human platelets: evidence for involvement of an inhibitory GTP-binding protein. Biochem. Biophys. Res. Commun. 144:1188-1196.

40. Brock, T., and E. Capasso. 1989. GTP,S increases thrombin-mediated inositol triphosphate accumulation in permeabilized human endothelial cells. Am. Rev. Respir. Dis. 140:1121-1125.

41. DeMarco, L., M. Mazzucato, A. Masotti, J. Fenton, and Z. Ruggeri. 199 Function of glycoprotein $1 \mathrm{~b} \alpha$ in platelet activation induced by $\alpha$-thrombin. $J$. Biol. Chem. 265:23776-23782. 